\title{
Brief Table of Contents
}

PREFACE $\quad$ xxix

ACKNOWLEDGEMENTS X $\quad$ xxxi

Chapter 1 EVOLUTIONARY BACKGROUND OF BIOSOCIAL INTERACTIONS

Chapter 2 INDIVIDUAL VARIATION AND INDIVIDUALISM 53

$\begin{array}{lll}\text { Chapter } 3 & \text { AGE VARIATION AND AGEISM } & 123\end{array}$

$\begin{array}{lll}\text { Chapter } 4 & \text { SEXUAL VARIATION AND SEXISM } & 183\end{array}$

Chapter 5 FAMILY VARIATION AND FAMILISM 253

Chapter 6 REPRODUCTIVE VARIATION AND PRO/ANTI-NATALISM 313

Chapter 7 SOCIAL CLASS VARIATION AND CLASSISM 375

Chapter 8 RACIAL VARIATION AND RACISM 437

Chapter 9 INTERGENERATIONAL VARIATION AND DYSGENISM 503

Chapter 10 ETHICAL AND POLICY CONSIDERATIONS REGARDING THE BIOSOCIAL FUTURE OF HUMANKIND 557

$\begin{array}{ll}\text { NAME INDEX } & 621\end{array}$

$\begin{array}{ll}\text { SUBJECT INDEX } & 661\end{array}$ 



\section{Detailed Table of Contents}

List of Tables $\quad$ xxi

List of Figures $\quad$ xxiii

Preface $\quad x x i x$

Acknowledgements $\quad$ xxxi

\section{CHAPTER 1: EVOLUTIONARY BACKGROUND OF BIOSOCIAL INTERACTIONS}

\section{INTRODUCTION}

THE BIOLOGICAL AND CULTURAL EVOLUTION

OF HUMANKIND

A BRIEF HISTORY OF THE STUDY OF BIOSOCIAL

INTERACTIONS

THE STUDY OF THE BIOLOGICAL EVOLUTION OF SOCIALITY 10

$\begin{array}{ll}\text { The evolution of social behaviour } & 14\end{array}$

$\begin{array}{ll}\text { The recent controversy about sociobiology } & 19\end{array}$

SIGNIFICANCE FOR THE SOCIAL AND BEHAVIOURAL

SCIENCES

FACTS AND VALUES IN BIOSOCIAL INTERACTIONS 27

The evolutionary origin and function of ethics 28

The 'Is/ought' controversy

THE SOCIAL BIOLOGY OF MODERNISATION 33

The major types of biosocial variation 36

The major biosocial challenges in modern culture 38

Individual variation and 'individualism' $\quad 40$

Age variation and 'ageism' $\quad 40$

Sexual variation and 'sexism' $\quad 41$

Family variation and 'familism' 41

Reproductive variation and 'pro/anti-natalism' 41

Social class variation and 'classisim' 42

Racial variation and 'racism'

Intergenerational variation and 'dysgenism' 43

Policy implications $\quad 43$

REFERENCES $\quad 43$ 


\section{CHAPTER 2: INDIVIDUAL VARIATION AND INDIVIDUALISM}

INTRODUCTION

EVOLUTIONARY BACKGROUND 55

Some basic genetic concepts $\quad 55$

The genetic unique identity of the individual $\quad 57$

$\begin{array}{ll}\text { Evolutionary mechanisms and individual variation } & 59\end{array}$

The Hardy-Weinberg law 59

$\begin{array}{ll}\text { Mutation } & 61\end{array}$

$\begin{array}{ll}\text { Selection } & 61\end{array}$

Genetic drift $\quad 62$

Genetic migration $\quad 62$

$\begin{array}{ll}\text { Partner choice } & 63\end{array}$

The level of selection: individual or group selection? 64

GENETIC AND ENVIRONMENTAL CAUSES OF INDIVIDUAL VARIATION 66

$\begin{array}{ll}\text { The obsolete nature-nurture discussion } & 67\end{array}$

Measuring the relative impact of genetic and environmental factors 68

$\begin{array}{ll}\text { The polygenic inheritance system } & 69\end{array}$

Dissecting the variance of quantitative traits $\quad 72$

Two sensitive matters: IQ and criminality... 76

$\begin{array}{ll}\text { The fractioning of } I Q & 76\end{array}$

Defining and measuring dimensions of cognitive abilities $\quad 77$

Heritability of intelligence $\quad 78$

The role of environmental factors in the development of intelligence 82

$\begin{array}{ll}\text { Criminal behaviour } & 85\end{array}$

$\begin{array}{lr}\text { Genetics and criminality } & 86\end{array}$

The neurosciences and delinquency $\quad 88$

Evolutionary biology and antisocial behaviour $\quad 90$

Concluding considerations concerning biology and crime 94

BIOLOGICAL SOURCES OF INDIVIDUAL VARIATION 95

$\begin{array}{ll}\text { General variation } & 95\end{array}$

Normality versus abnormality $\quad 96$

General variation within the 'normality' range 97

$\begin{array}{ll}\text { Age variation } & 97\end{array}$

$\begin{array}{lr}\text { Sexual variation } & 98\end{array}$

$\begin{array}{lr}\text { Racial variation } & 99\end{array}$

INDIVIDUAL-SOCIETAL INTERDEPENDENCY 99

$\begin{array}{lr}\text { The ontogenetic interdependency between individuals } & 100\end{array}$

The genetic interrelationship between individual and population 101

$\begin{array}{lr}\text { Individual competition versus social cooperation } & 103\end{array}$

INDIVIDUALISM IN MODERN SOCIETY 106

$\begin{array}{ll}\text { REFERENCES } & 109\end{array}$ 


\section{CHAPTER 3: AGE VARIATION AND AGEISM}

$\begin{array}{ll}\text { INTRODUCTION } & 125\end{array}$

GROWTH AND DEVELOPMENT 126

$\begin{array}{ll}\text { Evolutionary background } & 127\end{array}$

$\begin{array}{lr}\text { Secular growth acceleration } & 129\end{array}$

The increasing gap between biological maturation and social maturity $\quad 130$

AGEING AND SENESCENCE $\quad 131$

$\begin{array}{ll}\text { Evolutionary background } & 134\end{array}$

$\begin{array}{ll}\text { The evolutionary theory of senescence } & 134\end{array}$

Population genetic mechanisms of the evolution of senescence 135

Brain development and the evolution of the lifespan 137

Longevity and ageing/senescence 139

$\begin{array}{lr}\text { From a concave to a convex survival curve } & 139\end{array}$

From curve squaring to life extension? 143

$\begin{array}{ll}\text { Demographic implications of ageing } & 146\end{array}$

$\begin{array}{lr}\text { Population greying } & 147\end{array}$

$\begin{array}{ll}\text { Population dejuvenation } & 148\end{array}$

Societal implications of individual and population ageing 149

$\begin{array}{ll}\text { Attitudinal ambiguities } & 150\end{array}$

The expected increasing elderly dependency burden 152

The expected growing need for health and welfare care 153

Labour shortage 154

$\begin{array}{ll}\text { Intergenerational relations } & 154\end{array}$

Social differentials in longevity 156

DEATH 156

$\begin{array}{ll}\text { The biological meaning of death } & 157\end{array}$

$\begin{array}{ll}\text { The prolongation of the dying process } & 157\end{array}$

Death control 158

$\begin{array}{lr}\text { Palliative care } & 160\end{array}$

$\begin{array}{ll}\text { Euthanasia } & 161\end{array}$

Definition $\quad 161$

Legislation 162

Attitudes 162

$\begin{array}{ll}\text { Palliative sedation versus euthanasia } & 164\end{array}$

$\begin{array}{ll}\text { AGEISM } & 164\end{array}$

Ageist attitudes and behaviour towards seniors $\quad 165$

$\begin{array}{ll}\text { Social exclusion of seniors } & 165\end{array}$

Increasing gap between social and biological ageing in modern culture $\quad 166$

AGEING AND AGEISM IN EVOLUTIONARY PERSPECTIVE 167

$\begin{array}{ll}\text { REFERENCES } & 170\end{array}$ 


\section{CHAPTER 4: SEXUAL VARIATION AND SEXISM}

INTRODUCTION 185

EVOLUTIONARY ORIGINS OF SEXUAL VARIATION 186

Sexual selection $\quad 186$

Feminisation of the human male 188

Sexual evolution of the human female $\quad 190$

$\begin{array}{ll}\text { Evolution of sexual steering } & 191\end{array}$

Explanation of human sexual dimorphism $\quad 192$

ONTOGENETIC DETERMINANTS OF SEXUAL VARIATION 193

Sex and gender identity/role $\quad 193$

Socially important aspects of sexual determination and differentiation 196

MAJOR SOCIALLY RELEVANT CHARACTERISTICS

OF HUMAN SEXUAL DIMORPHISM $\quad 199$

Mind 200

Body build $\quad 204$

Genital sexuality 205

$\begin{array}{ll}\text { Reproduction } & 207\end{array}$

$\begin{array}{ll}\text { Health } & 208\end{array}$

OTHER SEXUALLY DIFFERENTIAL BEHAVIOURAL FEATURES 210

$\begin{array}{ll}\text { Crime } & 210\end{array}$

Homosexuality $\quad 211$

$\begin{array}{ll}\text { Proximate causes of homosexuality } & 212\end{array}$

Endocrinological findings $\quad 213$

$\begin{array}{ll}\text { Neurological findings } & 214\end{array}$

$\begin{array}{ll}\text { Genetic findings } & 214\end{array}$

$\begin{array}{ll}\text { Evolutionary explanations } & 215\end{array}$

$\begin{array}{ll}\text { Homophobia } & 218\end{array}$

$\begin{array}{ll}\text { The future of homosexuality } & 219\end{array}$

$\begin{array}{ll}\text { Sex-related social differences } & 220\end{array}$

$\begin{array}{ll}\text { Sexism } & 223\end{array}$

$\begin{array}{ll}\text { Sexist ideologies } & 224\end{array}$

Sexism, sexual emancipation, and science 225

Female social inferiority versus biological superiority: a paradox? 229

$\begin{array}{ll}\text { Feminism and masculism } & 230\end{array}$

MALADAPTATION OF SEXUAL DIMORPHISM IN MODERN CULTURE 235

$\begin{array}{ll}\text { REFERENCES } & 239\end{array}$ 


\section{CHAPTER 5: FAMILY VARIATION AND FAMILISM}

INTRODUCTION 255

BIOLOGICAL ORIGINS AND FUNCTIONS OF THE FAMILY 256

$\begin{array}{ll}\text { Parental investment in slowly-maturing offspring } & 257\end{array}$

$\begin{array}{ll}\text { The origin and evolution of love } & 258\end{array}$

FAMILIES IN MODERN CULTURE $\quad 261$

$\begin{array}{ll}\text { Recent trends in family (related) behaviour } & 261\end{array}$

Background of the modern family transition $\quad 264$

Determinants of recent family changes $\quad 266$

PARTNERSHIP IN MODERN CULTURE 267

$\begin{array}{ll}\text { Partner choice } & 267\end{array}$

Preferred and selected partner features $\quad 268$

Good genes theory 268

Parental investment theory $\quad 269$

Reproductive value theory $\quad 269$

Paternity confidence theory 273

$\begin{array}{ll}\text { Combined partner features } & 274\end{array}$

$\begin{array}{ll}\text { Mate selection } & 274\end{array}$

Sex assortment $\quad 276$

Kin assortment $\quad 276$

Assortative mating in general 280

$\begin{array}{ll}\text { Types of partnership } & 282\end{array}$

Single partnership $\quad 283$

Multiple partnerships $\quad 284$

$\begin{array}{ll}\text { Dynamics of partnership } & 286\end{array}$

$\begin{array}{ll}\text { Causes and consequences } & 287\end{array}$

THE FUTURE OF THE FAMILY 290

$\begin{array}{ll}\text { Disappearance of the family } & 291\end{array}$

Back to the traditional family? 293

Modern family variation $\quad 294$

What about the more distant future? $\quad 299$

$\begin{array}{ll}\text { REFERENCES } & 301\end{array}$ 


\section{CHAPTER 6: REPRODUCTIVE VARIATION AND PRO/ANTI-NATALISM}

\section{INTRODUCTION}

\section{THE EVOLUTIONARY BACKGROUND OF HUMAN}

REPRODUCTIVE BEHAVIOUR

General evolutionary trends with respect to reproduction

Maximisation of inclusive fitness

The paradox between maximisation of inclusive fitness and the demographic transition

Changed relations between phenotypic and genotypic fitness in modernisation

Sexual maturation

Pair bonding

Desired fertility / Childbearing motivation

Coital behaviour

Fecundity

Proceptive behaviour

Contraceptive behaviour

The contraceptive transitions in modern culture 331

Effects of the second contraceptive transition 334

Pregnancy

Effects of medical interventions

Spontaneous and induced abortion

Delivery and birth

Birth interval

Menopause

Sterility

Fertility

Fertility at the family level

Fertility at the population level 347

Below-replacement fertility $\quad 347$

Population dejuvenation 351

Population decline 352

Qualitative effects of the new fertility regime 354

Parenting

Evolutionary background: increased parental investment 357

Parenthood in modern culture 358

PRO- AND ANTI-NATALISM 359 


\section{CHAPTER 7: SOCIAL CLASS VARIATION AND CLASSISM}

INTRODUCTION

THE EVOLUTIONARY BACKGROUND OF WITHIN-POPULATION GROUP VARIATION

HISTORICAL THEORIES ABOUT BIOSOCIAL INEQUALITIES 380

The anthropo-sociological school of thought 381

Social Darwinism 382

Marxist biological doctrine $\quad 383$

THE SOCIAL-BIOLOGICAL APPROACH OF BIOSOCIAL INTERACTIONS 385

Social assortment and social selection $\quad 385$

$\begin{array}{ll}\text { Environmental influences } & 390\end{array}$

Genetic-environmental covariance $\quad 391$

SOCIAL STRATIFICATION AND BIOLOGICAL VARIATION 392

Body size and body build $\quad 392$

Growth and maturation $\quad 393$

Health and longevity $\quad 393$

Measured intelligence $\quad 394$

CAUSES OF INTERRELATIONS BETWEEN BIOLOGICAL VARIATION AND SOCIAL STRATIFICATION 395

Environmental influences linked to social status differences $\quad 395$

Social assortment: social mobility and biological variation 397

Empirical findings about the relationship between social mobility

and biological variation

Explanations of the relationship between social mobility and

biological variation

403

GENETICS AND SOCIAL MOBILITY 406

The assortment of phenotypes and genotypes $\quad 407$

Implications of segregation and recombination of genes 408

The role of mate choice in the social assortment of

biological characteristics

The controversy over 'The Bell Curve’ 416

EGALITARIANISM VERSUS MERITOCRACY? 419

REFERENCES $\quad 421$ 


\section{CHAPTER 8: RACIAL VARIATION AND RACISM}

INTRODUCTION

THE EVOLUTIONARY BACKGROUND OF BETWEEN-POPULATION

VARIATION

Splitting of populations

Fusion

Adaptation

BIOLOGICAL BETWEEN-POPULATION DIFFERENCES

Behavioural-genetic between-population differences

Jensen's 'default hypothesis' of between-population differences 4 in cognitive ability

The 'culture-only' hypothesis of between-population differences in cognitive ability

Drawing conclusions about the genetic-environmental controversy over between-population differences in cognitive ability

Evolutionary explanations for the origin of between-population

differences in cognitive ability

IN-GROUP/OUT-GROUP BEHAVIOUR 466

Typology 466

The cultural history of racism, ethnocentrism, and xenophobia 468

Behavioural patterns related to in-group/out-group relations $\quad 470$

Explanations for sociological dominant/subordinate relations 471

Inferior and superior populations? 472

EVOLUTIONARY EXPLANATIONS FOR THE IN-GROUP/OUT-GROUP

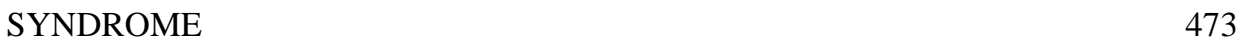

Kin selection theory $\quad 474$

Reciprocity theory $\quad 475$

Similarity theory 476

Selfish gene theory as basis for in-group/out-group antagonisms 477

Balance of power theory $\quad 478$

In-group/out-group syndrome: maladapted to the novel environment

of modern culture.

CULTURAL AUTONOMISM, INTEGRATIONALISM, OR

MULTICULTURALISM? $\quad 480$

Cultural autonomism/independence for historical ethnic components $\quad 481$

Integration of recent immigrant groups 482

Multiculturalism: fact or fiction? $\quad 484$

THE FUTURE OF BETWEEN-POPULATION DIFFERENCES
AND RELATIONS

$\begin{array}{ll}\text { REFERENCES } & 488\end{array}$ 


\section{CHAPTER 9: INTERGENERATIONAL VARIATION AND DYSGENISM}

INTRODUCTION 505

$\begin{array}{ll}\text { TIME DIMENSION } & 505\end{array}$

HERITAGE OF THE PAST 506

Biological heritage $\quad 507$

$\begin{array}{ll}\text { Cultural heritage } & 507\end{array}$

Conflicting and competing value and norm systems 508

$\begin{array}{ll}\text { Emergence of modern science } & 509\end{array}$

Effects of modern culture on intergenerational variation 509

Phenotypic effects $\quad 509$

Genetic effects $\quad 510$

Contra-selective effects of modern culture 513

$\begin{array}{ll}\text { Contraselective effects of replacement therapies } & 514\end{array}$

Contra-selective effects of differential reproduction with

respect to intelligence $\quad 515$

CRUCIAL CULTURAL DETERMINANTS FOR THE FUTURE 520

Future scientific and technological developments $\quad 520$

$\begin{array}{ll}\text { Ethical goals for the future } & 520\end{array}$

Euphenic goals $\quad 523$

Eugenic goals 523

The ultimate aim of eugenics: carrying forward the hominisation
process

Rationale for the preservation and the advancement of

human-specific characteristics $\quad 527$

General societal conditions for implementing a eugenic programme 529

Scientific and social dimensions of eugenics $\quad 530$

Broad and narrow eugenics $\quad 531$

Eugenic target levels $\quad 531$

Eugenic benefits and costs $\quad 532$

Eugenic fallacies of the past $\quad 534$

ETHICAL CONCERNS 538

Ethical concerns about eugenics in general $\quad 538$

$\begin{array}{ll}\text { Ethical issues in eugenic practice } & 541\end{array}$

Attitudes towards eugenics $\quad 544$

REFERENCES $\quad 545$ 
xviii

\section{CHAPTER 10: ETHICAL AND POLICY CONSIDERATIONS REGARDING THE BIOSOCIAL FUTURE OF HUMANKIND}

\section{INTRODUCTION}

BASIC ETHICAL OPTIONS RELEVANT FOR THE BIOLOGICAL FUTURE OF THE HUMAN SPECIES

Intervention versus non-intervention

Quality versus quantity

Equality versus inequality

Cooperation versus competition

Out-group versus in-group

Intergenerational versus intragenerational care

Individual variation 569

Difference $\neq$ inequality 569

Adjusting individual aspirations to societal demands 572

Age variation

Active ageing - sense of reality or lip service?

Combatting ageism - adapting to ageing 574 Increasing age at retirement 575

Varying age at retirement 576

Death control 577

Sexual variation 577

Reconciliation of productive and reproductive functions 578

Empowerment of women 579

Mastering male competitive behaviour 581

Family variation $\quad 582$

Reproductive variation 583

Policy implications regarding fertility control 584 Policies regarding contraception $\quad 584$

Policy implications regarding abortion $\quad 585$

Policy implications regarding fertility 586 Policy goals regarding fertility $\quad 586$

Feasibility of policy measures regarding fertility 587

Policy measures for redressing fertility at or around replacement level 588

Rebalancing individual and societal values with

respect to intergenerational continuity

Rethinking the entire life course perspective regarding

education, employment and retirement 589

Within-population group variation $\quad 592$

Inter-population variation 593 
Reducing between-group inequalities

Combating the in-group/out-group syndrome 595

Exposing the false notion of multiculturalism 596

Intergenerational variation $\quad 597$

Euphenic engineering $\quad 597$

Eugenic engineering 598

Biotechnology $\quad 599$

Genetically differential demographic behaviour $\quad 600$

$\begin{array}{ll}\text { Individual/family oriented eugenics } & 600\end{array}$

$\begin{array}{ll}\text { Population oriented eugenics } & 601\end{array}$

How to achieve differential reproduction? $\quad 605$

THE FAR FUTURE $\quad 606$

Evolutionary extinction $\quad 608$

$\begin{array}{ll}\text { Evolutionary regression } & 609\end{array}$

$\begin{array}{ll}\text { Evolutionary stabilisation } & 609\end{array}$

$\begin{array}{ll}\text { Evolutionary progression } & 609\end{array}$

REFERENCES $\quad 611$

$\begin{array}{ll}\text { NAME INDEX } & 621\end{array}$

SUBJECT INDEX 